\title{
The Queer Post-Migratory Writings of Christos Tsiolkas: (Re)locating Mental and Sexual Disorders of "Translated" Subjects
}

\section{Sophie Coavoux}

\section{OpenEdition \\ Journals}

Electronic version

URL: http://journals.openedition.org/transtexts/788

DOI: $10.4000 /$ transtexts.788

ISSN: 2105-2549

Publisher

Gregory B. Lee

Electronic reference

Sophie Coavoux, "The Queer Post-Migratory Writings of Christos Tsiolkas: (Re)locating Mental and

Sexual Disorders of "Translated" Subjects ", Transtext(e)s Transcultures 跨文本跨文化 [Online],

12 | 2017, Online since 09 July 2018, connection on 01 May 2019. URL : http://

journals.openedition.org/transtexts/788; DOI : 10.4000/transtexts.788

This text was automatically generated on 1 May 2019.

(c) Tous droits réservés 


\title{
The Queer Post-Migratory Writings of Christos Tsiolkas: (Re)locating Mental and Sexual Disorders of "Translated" Subjects
}

\author{
Sophie Coavoux
}

Christos Tsiolkas's prose fiction is full of suffering souls and bodies, "lost in translation", a characteristic often identified as a topos of so-called migration literature or migratory writings. ${ }^{1}$ Indeed, through the prism of the complex entanglements of the themes of migration and disease, the whole corpus of Christos Tsiolkas provides a wide range of disorders that affect the minds and the bodies of his "translated" subjects (mainly depression, dementia, self-destruction, gender and sexual troubles). His controversial representations of hyphenated subjects provide a critique of identities and identity politics through his interpretation of the unhealthy imaginary of the migrant. Furthermore, those numerous disorders affecting his novels' characters are interwoven with the ambiguous encounters between "inside" and "outside" perceptions, through a dialectical conflict between "identity" and "otherness", following a process of internalization of dysphoric unhealthy representations, similar to what Franz Fanon termed the "epidermalization of inferiority". ${ }^{2}$ In relation to this, Christos Tsiolkas's writings also explore, as one of its major themes, hate and self-hatred, described as a universal component, to demonstrate, like Fanon, that hate and racism (extended to ethnicity, social class, gender, sexuality) is a collective neurosis that affects all human beings. This is expressed by the protagonist of Loaded who believes "Everyone hates everyone else", and that "a web of hatred connects the planet". ${ }^{3}$ Exploring those complex issues, Christos Tsiolkas seems to go beyond any binary approach or any kind of Manichaeism based on a simplistic and superficial opposition between the "same" and the "other", categories which coincide with those of the "healthy" and the "unhealthy". According to him, otherness does not exist per se, as an essence, but rather forms itself in relation with the others and the self: in this sense, the philosophical background of his work comes across in Paul Ricœur's Oneself as Another. ${ }^{4}$ Lastly, through the renewal of the 
cartography of otherness and partly by the way in which he subverts and relocates the unhealthy imaginary of his translated subjects, Christos Tsiolkas's writings can be considered an example of queer post-migratory literature.

\section{"Translated" Subjects within "imaginary homelands"}

Christos Tsiolkas is a Greek Australian writer whose work is informed by the themes of migration and exile, but also gender, sexuality, "race" and family. Often regarded as the "enfant terrible" of contemporary Australian literature, he is mostly famous for his provocative forays into the sexual and ethnic politics of multicultural Australia. Author, playwright, essayist and screenwriter, since 2005, he has so far published six novels: Loaded, The Jesus Man, Dead Europe (which won the 2006 Age Fiction Prize and the 2006 Melbourne Best Writing Award). ${ }^{5}$ He has been mostly acclaimed for his multi-award winning novel The Slap. ${ }^{6}$ Barracuda is his fifth novel. His 2014 book, Merciless Gods was not a novel but a collection of short stories. ${ }^{7}$ It should be mentioned that Christos Tsiolkas is an Anglophone writer even if he writes on occasion in Greek and translates his prose himself.

Being a "second-generation Australian of Greek origin", he portrays in his novels a myriad of characters who illustrate the failure of multicultural Australia where a mix of people from various and hybrid origins live together with the so-called "Aussies". More broadly, Christos Tsiolkas is engaged with the migration theme in general, and the now globalized flows of people, migration becoming a globalized experience. He shows the blurring of identities through his characters, whether migrants or the "original" inhabitants of the host country. His writings could be analysed as an attempt to rethink diversity, at a collective and at an individual level, in order to show the ambivalences between the construction/deconstruction of the self and the complex relationships between the self and the other.

Almost all his characters, protagonists or not, are marked by the migratory experience, the issue of belonging being interwoven in many cases with a process of acculturation and, as a consequence, they are characterized by different forms of uneasiness. Whether or not they have been experiencing migration themselves, all of them seem to be marked, and affected, if not traumatized, by migration, in their mind and in their flesh, and all of them can be characterized as "translated" subjects, as Salman Rushdie has it in his Imaginary Homeland. ${ }^{8}$ In this way they also fit the conceptualization of "translation" coined by Stuart Hall which:

describes those identity formations which cut across and intersect natural frontiers, and which are composed of people who have been dispersed forever from their homelands. Such people retain strong links with their places of origin and their traditions, but they are without the illusion of a return to the past. They are obliged to come to terms with the new cultures they inhabit, without simply assimilating to them and losing their identities completely. They bear upon them the traces of the particular cultures, traditions, languages and histories by which there were shaped. The difference is that they are not and will never be unified in the old sense, because they are irrevocably the product of several interlocking histories and cultures, belong at one and the same time to several 'homes' (and to no one particular 'home'). People belonging to such cultures of hybridity have had to renounce the dream or ambition of rediscovering any kind of 'lost' cultural purity, or ethnic absolutism. They are irrevocably translated. The word 'translation', Salman Rushdie notes, 'comes etymologically from the Latin for "bearing across'". 
Migrant writers like him, who belong to two worlds at once, 'having been borne across the world... are translated men' (Rushdie, 1991). They are the products of the new diasporas created by the post-colonial migrations. They must learn to inhabit at least two identities, to speak two cultural languages, to translate and negotiate between them. Cultures of hybridity are one of the distinctly novel types of identity produced in the era of late-modernity, and there are more and more examples of them to be discovered. ${ }^{9}$

By drawing up a typology of Christos Tsiolkas's characters, it appears that an overwhelming majority of them have an immigrant background, shaping a multicultural, multiethnic and multireligious cast, along with a few Aboriginal and Anglo characters: Greeks, Indians, Serbians, Italians among others, Catholics, Christian Orthodox, Muslim, Jews. For sure, if all his protagonists fit this category and that characterization is obviously always presented as central in the narrative, "that does not mean that ethnicity becomes a totalizing form of characterization". ${ }^{10}$ Furthermore, Christos Tsiolkas's characters often possess hybrid origins: for example, a Canadian of Chinese and Czech origin, mixed nationality couples (Indonesian and Greeks from Georgia) and so on. But it has to be noticed that for most of them, they have not themselves experienced migration, but rather are of migrant descent, and significantly the protagonists of his novels are second-generation subjects. On this point, the epigraph of Loaded is quite significant. It is a quotation from the writer Richard Rodriguez's book An American Writer:

The immigrant child has the advantage or the burden of knowing what other children may more easily forget: a child, any child, necessarily lives in his own time, his own room. The child cannot have a life identical with that of his mother or father. For the immigrant child this knowledge is inescapable.

\section{"I xenitia" and the Inheritance of "migration disease"}

Thus, it seems as in Christos Tsiolkas's perception, migration is not only something empirical, a lived experience. It is also an inheritance, a memory, if not a curse or a type of atavism. Therefore, as second-generation subjects, his characters suffer from a kind of migration disease with various symptoms (mostly psychological), as a consequence of the (xenitia) inherited from their parents. This untranslatable Greek term (xenitia) is an ambiguous concept with multiple meanings: foreign (host) land, exile, homeland, homesickness, to live as a stranger in a foreign land. ${ }^{11}$ Even if, according to Hariclea Zengos, the xenitia theme dealt with by second-generation writers appears to express a sense of exile "of a different nature" from that of first generation writers, it remains central in the narrative, even if they focus on the exploration of hyphenated hybrid identities. $^{12}$

The inheritance of the "migration" disease is a leitmotiv in The Jesus Man, a novel that tells the story of one family, torn between conflicting identities: while the parents are Greek and Italian, their three sons, Dom, Tommy and Luigi Stephano, have grown up as Australians. All the members of the family are literally haunted by their history and their origins. In particular, Maria, the mother, who is not only unable to escape the harsh taste of exile, but has transmitted her uneasiness provoked by homesickness (xenitia) to her son Tommy, who, because of "the overwhelming presence of the past", finds himself inexorably caught up in a vicious circle of violence, pornography and madness that will tragically end with a crime and a suicide. ${ }^{13}$ Migrant parents transmit to their children a 
feeling of homelessness and the ghosts of their "imaginary homeland" which become a burden. ${ }^{14}$

But the second-generation children are not looking for their supposed original homeland, aware that it is impossible for them to live in it. In The Jesus Man, Luigi Stefano expresses that very clearly: "In Greece I could not be Greek. In Perth I cannot feel Australian". ${ }^{15}$ Even their migrant parents see them neither as Greek nor as Australian. In The Jesus Man, Maria the mother says to her son: "you're nothing". ${ }^{16}$ Furthermore, outside their families, the migrant children, generally considered by the others to be "wogs" (a racist term generally used for "migrants of colour"), are not even recognized as such by the other "wogs", as described by Luigi:

When we cut ourselves from the Greek tongue, we also cut ourselves off from the Greeks. This was probably inevitable, nothing any of us did could have stopped it. My mother, the only one of us a migrant and therefore unapologetic for her right to be a Greek, thinks we're a failure as a migrant family, not a success story to write back home about. But I guess that's the rub: we weren't really a migrant family. I'm not even a wog. Or at least that's what the wogs tell me.

I'm very self-conscious about who I am. ${ }^{17}$

Not even having experienced migration, but being rejected from both sides, the putative homeland and the so-called host country, Christos Tsiolkas's protagonists are caught up in a paradoxical situation: haunted by a past/a country which is not theirs, neither can they fit into a present/a place to which they do not belong. ${ }^{18}$ Consequently, they reject both. Thus, the protagonists of Loaded, The Jesus Man, Barracuda and Dead Europe, all remaining "translated subjects", feel rootless, as if they belong nowhere or to a "noman's land", and they suffer harshly from their state of constant and suffocating inbetweeness.

For them, the "imaginary homeland" provokes a phantom pain comparable to that of an amputated limb. So they all struggle to find their own personal identity, rejecting all conventional identity labels, and seem to be lost amidst conflicting representations of ethnicity, gender and sexuality. For example, Ari, the protagonist of Loaded says:

I'm not Australian, I'm not Greek, I'm not anything. I'm not a worker, I'm not a student, I'm not an artist, I'm not a junkie, I'm not a conversationalist, I'm not an Australian, not a wog, not anything. I'm not left wing, right wing, center, left of center, right of Genghis Khan. I don't vote, I don't demonstrate, I don't do charity. What I am is a runner. Running away from the thousand and one things that people say you have to be or should want to be. ${ }^{19}$

\section{Identities in (Mental and Sexual) Trouble}

Showing a predilection for extreme experiences, Christos Tsiolkas expresses the uneasiness that characterize most of the translated subjects through extreme situations engaging their health. To say the least, Christos Tsiolkas's protagonists are not healthy. On the contrary, they suffer from multiple mental and sexual troubles, their alienation being linked to their inherited migration disease. Their minds and bodies are prey to illness and disability, as they suffer from depression, dementia, eating disorders/obesity, violence, self-destruction, gender and sexual troubles, and, as a consequence, they are exposed to marginalization, social exclusion and psychic alienation. In Loaded the protagonist Ari gets "wasted", or "loaded", on drugs and sex, just as Tommy, the highly depressed character of The Jesus Man who after losing his job gets lost in pornography and food. Or significantly the protagonist of Barracuda, whose name is Daniel Kelly, a 
translated subject of Greek and Scottish immigrant parents, is nicknamed "Psycho", this nickname being inherited from an outbreak of violence that lead him to beat a friend almost to death.

Whether they suffer from visible or invisible disabilities, they are marked by a stigma with negative effects on their sense of belonging. Christos Tsiolkas describes those translated characters as identities in trouble whose uneasiness is not only related to ethnicity but also to gender and sexuality.

The most important is that, regarding their sexuality, a number of the characters perceive themselves (or are perceived) as ill and they think they suffer from perversity or hypersexuality. It has to be underlined that most of the protagonists are gay men, and that there is no "gender balance" in Tsiolkas's writings. Having internalized the stereotype of the over-sexed Mediterranean man, some of them identify with it. ${ }^{20}$ In particular Greeks are described as sex maniacs, as in The Jesus Man ("randy little buggers. They'd fuck anything"). ${ }^{21}$ Others think they are perverse, like Tommy who thinks he is a sexual pervert by birth (The Jesus Man), a central component in his feeling of being a freak: obscene and obese flesh. ${ }^{22}$ In addition to this, this sickly self-representation is linked to sexual orientation. In Loaded, Ari offers an example of a homophobic gay subject: arguing he has no problem with his homoerotic desires and life, he paradoxically reinforces the dominant heterosexual male culture and the current homophobia he has internalized, rejecting a lover, George, because, according to him, he has been feminized. His conflicting emotions and perceptions are quite similar to those of Luigi Stephano in The Jesus Man. Sharing the same libidinal and ethical difficulties, he thinks:

Homosexuality is a sickness. So, probably, being hetero. Being black is a sickness, so too is being white. ${ }^{23}$

The depiction of the health of translated subjects is undoubtedly dysphoric as Tsiolkas shows a predilection for characters suffering from various mental and physical health problems, being mentally tormented by troubled sexual, ethnic, class and gendered identities: alienation seems to be the actual outcome of migration. But if there is indeed a reality of psycho-traumatic experiences linked to migration, the crisis of belonging described by Tsiolkas is largely due to the internalization of racist stereotypes (in the larger sense of the word, racism being extended to ethnicity, social class, gender, sexuality), a form of what Frantz Fanon called "epidermalization of inferiority" the dominated being "the slave of their archetypes". ${ }^{24}$ In this way, the representation of suffering/ill translated subjects seems to function like a metaphor of the corporeality of a symbolic order ruled by multi-layered hierarchies related to class, sexuality, gender, or ethnicity. This is exemplified by Daniel, Barracuda's protagonist, whose athletic body is healthy - at least when, as a young boy, he had the ambition to become a champion swimmer, before collapsing and getting fat - is exposed to a double jeopardy due to his ethnic and class background, along with his gay sexual orientation, which make him feel sick - a phenomenon marked by quite frequent occurrences of the semantic field of sickness. Coming from a working-class family in the suburbs of Melbourne, when he wins a sport scholarship to a private school, he remains an outsider in the middle of a majority of hostile "golden boys", and faces grave problems of belonging, which make him sick. From the first time he reaches his new school, he feels like a stranger, and his feeling of otherness morphs into self-disgust, hate and self-hatred:

He hated them, he absolutely hated them, the golden boys. He hated their

blondness, their insincere smiles, their designer sunglasses, their designer 
swimmers and their designers sports gear. They made him feel dark and short and dirty. ${ }^{25}$

In particular, he has to shave his own hairy body for competing makes him sick, operating as a corporeal metaphor embodying his difference with the other boys:

He forced his eyes back to his reflection in the mirror. What repelled him instantly was all that hair. It disgusted him. [...] There were ugly clumps of it across his chest, down his belly, dense back thatches of it under his arms. He hated how it was crawling up to his shoulder blades, he saw it as a virus invading his body, the explosion of it from his crotch, how it crept up his legs and grew thicker and blacker on his thighs. One day he would get it all waxed, have an operation to get rid of it, the whole filthy mess of it. It sickened him. ${ }^{26}$

Ultimately, the hate that grows inside him becomes the main source of his feeling of being sick: "it sickened him how much hate he had inside him. All I am, thought Dan, is hate". ${ }^{27}$

\section{Hate/Self-hatred as a Collective Psychosis}

Indeed, in Christos Tsiolkas's writings, the most important form of illness is hatred, selfhatred and racism, which appears to be a collective psychosis. Under a variety of forms linked to ethnicity, gender, sexuality, disability, religion or class, the hate issue is very central to Christos Tsiolkas's work, as it is always interconnected with the theme of migration. His novels function like a compendium, or archive, of racist insults and verbal racist attacks uttered by members of the same or different communities, thus transcending a binary conception of the "same" and the "other". Self-hatred, as a consequence of the internalization of racist representations and shame, is above all a major theme developed by Christos Tsiolkas.

In his last book Merciless Gods published in 2014, which is a compilation of short stories told from diverse cultural perspectives (Greek, Italian, Turkish, English and Iranian), hate is everywhere, which is made clear by the pervasiveness of racist insults: "wog", "dago", "reffo", sexist ones "bitch", "faggot" etc. Merciless Gods can be identified as a snapshot of migrant cultures clashing where this universal hate appears between communities and even inside them - it is worth noting that there are around one hundred occurrences of the terms "hate", "hatred" and "self-hatred" in the book. And it is important to stress that there is no solidarity between the suffering migrant or in-between characters, mainly because of the collision of sexual, ethnic and class boundaries. An example of multilayered hate and racism occurs in Barracuda where Danny, the half Scottish, half Greek protagonist, finds himself insulted by the other immigrant children at school who consider "the faggot isn't even a true wog". ${ }^{28}$

What is particularly interesting in Christos Tsiolkas's novels is the depiction of the hatred of the other inside us and Tsiolkas shows that what we call hatred of the other is in fact, on the down side, self-loathing. The most significant, and also controversial, example is given by the novel Dead Europe, a kind of realistic gothic tale recounting the protagonist Isaac's macabre tour around Europe, through Italy to the United Kingdom, which becomes a descent into hell. Beyond the protagonist's psychic and bodily alienation, Tsiolkas's Europe is described by Janine Hauthal as a "traumascape". Graham Huggan calls it "a place seemingly condemned to repeat its own violently self-destructive history": 
Haunted by spectres of its own making, it is a deadened - but also deadly - site of corrupt pimps and destitute sex workers, caught in a vicious web of race and classbased exploitation [...] Tsiolkas's Europe [...] is a far cry from the fount of idealistic humanism dreamed up by generations of both pre- and post-Enlightenment politicians and philosophers, a Europe defined by its durable capacity for civility in an otherwise barbarous world. ${ }^{29}$

As he returns to Greece, where he visits his mother's village, the protagonist Isaac, an Australian photographer of Greek descent, morphs into a vampire. Inheriting his family's curse, he is haunted by the ghost of a Jewish boy, who turns out to be his own grandfather, murdered by his ancestors, who has colonized his body and his photographs. Consequently, Isaac finds himself colonized "by the curse lurking atavistically within him". ${ }^{30}$ Christos Tsiolkas's choice to explore the gothic figure of a vampire is not a coincidence. ${ }^{31}$ According to Johan Höglund and Tabish Khair "The vampire has always been a traveller and the vampire story frequently explores national, sexual, racial and cultural boundaries":

Through its itinerant ways and transformative body, the old and modern vampire take the reader on trips from the Imperial metropolis into the colonial periphery, to the places where East and West intersect, where stable cultural categories clash, collapse and transform, allowing both the human and the political body to take new and often disturbing forms.

Thus, the vampire narrative effectively and continuously maps transnational, colonial and postcolonial concerns. ${ }^{32}$

As a metaphor, the vampire has the potential here to embody a state of in-betweenness. Even if it has been argued by some critics that Tsiolkas's use of this vampiric figure is ambivalent as it encounters anti-Semitic themes, the author on the contrary subverts or reverses the cliché of the anti-Semitic vampire. Indeed, Dead Europe's "central ploy" is to "take the great phobic structures underlying Western vampire discourse - anti-Semitism, fascistic nationalism, ethnic absolutism, homophobia - and, by dismantling their myth of origin, to use them to reflect on the ravaged history of the West itself". ${ }^{33}$

Because of this family curse, not only does Isaac morph into a vampire (which makes him sick and annihilates him: "This journey seems to be taking me further away from myself, from all my certainties, from even a sense of my own origins"), he is also exposed to the transmission/contamination of viral anti-Semitism, xenophobia and racism. ${ }^{34}$ Exploring the theme of anti-Semitism and its modern forms in Europe, along with other forms of racism and hate, Christos Tsiolkas focuses on individual ossimoric and schizophrenic conflicts that Isaac encounters: his own blood might be Jewish but at the same time he is exposed to anti-Semitic sentiments. ${ }^{35}$

Thus, Christos Tsiolkas's controversial and quite risky exploration of anti-Semitism cannot allow any anti-Semitic reading of the novel. The understanding of the complex appropriation of anti-Semitic discourse in Christos Tsiolkas's Dead Europe is possible through the contextualization of the broader topic of hate/self-hatred, which is not restricted to Jewishness nor Jewish self-hatred. Here, Christos Tsiolkas illustrates and scrutinizes paradoxes and apparent contradictions between hate and self-hatred, between the other and the self, through the interiorization and contamination of dysphoric and hate-filled representations of the other, applied, as mentioned above, to ethnicity, sexuality, gender and any form of otherness. ${ }^{36}$ The author transcends the ontological binary scheme opposing the same and the other, going beyond the paradigm of the victim, exploring humankind's shadowy areas, including the Baudelairian figure of “The Self-Tormenter" (in French, L'Héautontimorouménos, a poem found in the collection 
Les Fleurs $\mathrm{du}$ Mal). In this way, hate and self-hatred are described as both part of the same self-sustaining mechanism, a manifestation of social marginalization and an expression of anger for those who are, or who feel, being rejected due to their "difference", and who, as a consequence, find themselves a stranger and exiled from the self.

In this way, Christos Tsiolkas refuses the mechanisms ruled by binarism as he resolves the irreducible fracture between the same and the other, every stereotype collapsing under the complex configurations he elaborates in his novels. His reshaping of "migrancy" comes close to Iain Chambers's conception in the way, invoking Julia Kristeva, he defines the "stranger":

As such the stranger is an emblem - she or he is a figure that draws our attention to the urgencies of our time: a presence that questions our present. For the stranger threatens the 'binary classification deployed in the construction of order', and introduces us to the uncanny displacement of ambiguity. That stranger, as the ghost that shadows every discourse, is the disturbing interrogation, the estrangement, that potentially exists within us all. It is a presence that persists, that cannot be effaced, that draws me out of myself towards another. It is the insistence of the other face that charges my obligation to that 'strangeness that cannot be suppressed, which means that it is my obligation that cannot be effaced'. As "the symptom that renders our "selves" problematic, perhaps impossible, the stranger commences with the emergence of the awareness of my difference and concludes when we all recognise ourselves as strangers. ${ }^{37}$

\section{Post-Migratory and Queer Writings}

The main source of uneasiness and disease in Tsiolkas's narrative originates from the problem of belonging and the search for identity in a migratory global context, his critique being intrinsically intersectional and showing how biopower acts notably on translated subjects's embodied experience (including on their subjectivity), describing their body encapsulating alterity related to the nation, sexuality and so on. In this way, he subverts the figure of the stranger, and thus avoids any ontology of strangeness. ${ }^{38}$

In order to conclude, we shall argue that Christos Tsiolkas's writings provide an example of queer post-migratory literature. The term "post-migratory" coined by Caryl Philipps, is quite relevant to Christos Tsiolkas's ethos, in the way he breaks down the constraints of ethnicity and national characteristics, implementing a new sense of identity and belonging. ${ }^{39}$ Thus, in Dead Europe, according to Parlati, Tsiolkas shows that "roots are mischievous, mystifying, annihilating". ${ }^{40}$ Even more, beyond its thematic approach, the situation of Tsiolkas's writing within literature can be described as post-migratory, rather than simply migrant. If for instance Dead Europe is "ultimately neither European nor Australian", neither is it an example of Greek Australian literature. ${ }^{41}$ It is rather a "global novel", or a transcultural one, where the literary imaginary allows reshaping so-called migrant identity. ${ }^{42}$ In addition, trying to escape every attempt of ethnic definition or any "floating signifier", to use Sneja Gunew's words, Christos Tsiolkas thus could also be defined as a "post-multicultural writer", disrupting the reading that would confine him to being just an "ethnic" (gay) writer. ${ }^{43}$

Within a larger discussion around the relationship between migration and literature, the paradigms of "migrant literature" and "migration literature" are at the core of a debate within scholars, and central to the discussion is Elleke Boehmer's attempt to redefine texts of the early 2000s as "post-migratory": 
Such 'post-migratory', 'post-postcolonial' writing, as 'postmigratory' black British writer Caryl Phillips terms it, explores not only leave-taking and departure, watchwords of the migrant condition, but also the regeneration of communities and selves out of heterogeneous experiences in the new country. To find ways 'to begin again and go on' is today's imperative. The creative landscape that emerges from this impulse can be schematized not only as a multitude of divergent margins (which in terms of the recognition of differences it of course is), but also as a collection of at times connected and overlapping yet distinct centres and regions, which would include constituencies of once-migrant writers. My use of spatial metaphors here is intentional. Decentring the centre in many cases involves embodying, materializing, or giving spatial form to what were previously regarded as one-dimensionally temporal and even ahistorical terms: weightlessness, migrancy, in-betweenness, cultural pluralism, postcolonialism. ${ }^{44}$

More importantly, this paradigmatic shift beyond the blanket category of migrant literature and toward a post-migratory writing conception is particularly interesting as it fits better with another characteristic of Christos Tsiolkas's work. His novels are indeed an outstanding example of queer literature as his work provides "a queer kind of belonging", clearly situating himself within the parameters of a post-identitarian and post-belonging queer politics. ${ }^{45}$ Thus, "queer" does not only challenge gender and sexual norms but also a variety norms, if not all kind of norms:

Queer is by definition whatever is at odds with the normal, the legitimate, the dominant. There is nothing in particular to which it necessarily refers. It is an identity without an essence. "Queer", then, demarcates not a positivity but a positionality vis-à-vis the normative [...] [Queer] describes a horizon of possibility whose precise extent and heterogeneous scope cannot in principle be delimited in advance. ${ }^{46}$

Within a wider intersectional post-identitarian landscape, the queer paradigm has the potential to extend beyond the gender agenda, including other categories in the construction of otherness, as they converge under the label of hybridity ${ }^{47}$ Since his first novel, published in 1995, Christos Tsiolkas goes beyond a gay politics and the paradigm of identity, as he criticizes any identity label. Being subject of multi-minority groups, the protagonist of Loaded, Ari, defines himself through a process of counteridentification. ${ }^{48} \mathrm{He}$ rebels against the model of normativity and conformity, in a very provocative way, as he says:

Faggot I don't mind. I like the word. I like queer. I like the Greek word pousti. I hate the word gay. Hate the word homosexual. I like the word wog, can't stand dago, ethnic or Greek-Australian. You're either Greek or Australian, you have to make a choice. Me, I'm neither; it's not that I can't decide; I don't like definitions. If I was black, I'd call myself nigger. ${ }^{49}$

Remaining in the same register as Barracuda, published in 2013, the end of alienation coincides for Danny the protagonist with the moment he understands that "belonging [...] was the wrong question":

Belonging, he knew now, was the wrong question. The context between country and nation, the tussle between home and roaming, here and elsewhere, all the relentless claiming and the ever-shifting mapping, none of it could settle the question that had mattered most to him since he'd found himself moored on dry land: was he - Danny Kelly, Psycho Kelly, Danny the Greek, Dino, Dan, Barracuda was he a good man? He needed to answer that first, and then all would fall into place..$^{50}$ 
Christos Tsiolkas gives voice in his work to a variety of multilayered translated subjectivities and his acknowledgement of personal identities does not coincide with any form of politics, as expressed by Ari in Loaded ("I sing fuck politics, let's dance"). ${ }^{51}$ While criticizing the traditional framing of (both ethnic and gender) belonging, he contributes to dismantling any binary essentialist scheme and any assigned and fixed identity against which he supports an identity and culture model in terms of lability, movement and migrancy. While the sense of belonging is constantly being eroded by modern society, Tsiolkas's queer and post-migratory writings can thus be defined also as post-belonging. This conception offers the possibility of going beyond and subverting the dysphoric unhealthy representations of translated subjects, whilst the queer and post-belonging paradigms perhaps provide a type of therapy for both identity troubles and identity politics.

\section{NOTES}

1. Concerning Greek-Australian literature, see: Andrea Garivaldis, The Evolution of Greek Identity through the Study of Selected Short Stories of Greek Australian Writers: 1901-2001, in M. Rossetto, M. Tsianikas, G. Couvalis and M. Palaktsoglou (Eds.), Greek Research in Australia: Proceedings of the Eighth Biennial International Conference of Greek Studies, Flinders University, 2009, p. 280-290. George Kanarakis, Greek Voices in Australia: a Tradition of Prose, Poetry and Drama, Sydney, New York, Australian National University Press, 1987. Con Castan, "Greek-Australian Literature: An Essay" in Spilias, T. and Mesinis, S. (eds), Reflections: Selected Works from Greek Australian Literature, Melbourne, Elikia Books, 1988, p. 3-28. Con Castan, "Greek-australian literary publication", Modern Greek studies, Australia, New Zeland, 2, 1994.

2. Frantz Fanon, Black Skins, White masks, Translated by Charles Lam Markmann, Forewords by Ziauddin Sardar and Homi K. Bhabha, London, Pluto Press, 2008, p. 4.

3. Christos Tsiolkas, Loaded, London, Vintage Books, 1997, p. 51, 64.

4. Paul Ricoeur, Oneself as Another, translated by Kathleen Blamey, Chicago, The University of Chicago Press, 1992 (originally published under the title: Soi-même comme un autre, Paris, Seuil, 1990).

5. Loaded, London, Vintage Books, 1997; The Jesus man, North Sydney, NSW, Random House Australia Ply Ltd, 1999 (Kindle electronic book); Dead Europe, London, Atlantic Books, 2011 (first published in Australia by Random House Australia Ply Ltd, 2005).

6. The Slap, Crows Nest, NSW, Allen \& Unwin, 2008.

7. Barracuda, London, Atlantic Books, 2014 (first published in Australia by Allen \& Unwin, 2013); Merciless Gods, Crows Nest, NSW, Allen \& Unwin, 2014.

8. See Salman Rushdie, Imaginary Homelands. Essays and Criticism 1981-1991, London, Granta (in association with Penguin Books), 1992, p. 17: “The word 'translation' comes, etymologically, from the Latin for 'bearing across'. Having been borne across the world, we are translated men. It is normally supposed that something always gets lost in translation; I cling, obstinately, to the notion that something can also be gained." See also Homi Bhabha, The location of culture, London, New York, Routledge, 1994 (see the last chapter "How newness enters the world: Postmodern space, postcolonial times and the trials of cultural translation", p. 212). 
9. Stuart Hall, The Question of Cultural Identity, In: S. Hall, D. Held and T. McGrew (Eds.), Modernity and Its Futures, Milton Keynes, Cambridge, Open University Press, 1992, p. 310.

10. Andrew McCann, Christos Tsiolkas and the Fiction of Critique: Politics, Obscenity, Celebrity, London, Anthem Press, 2015, p. 106.

11. See Pavlos Kavouras, University of Athens, "Xenitia or the State of Being a Foreigner: Juxtaposing Realities, Interpreting Encounters". Retrieved from https://lsa.umich.edu/ modgreek/news-events/all-events.detail.html/25098-1654342.html

12. See Hariclea Zengos, "Re-defining Parameters: Greek Australian Literature”, In: Reading Down Under: Australian Literary Studies Reader, Amit Sarwal and Reema Sarwal (Eds), New Delhi, SSS Publications, 2009, p. 271-282.

See also Garivaldis, The Evolution of Greek Identity, p. 285, 288.

13. See Tsiolkas, The Jesus man, 3527.

14. See Rushdie, Imaginary Homelands, p. 10: "It may be that writers in my position, exiles or emigrants or expatriates, are haunted by some sense of loss, some urge to reclaim, to look back, even at the risk of being mutated into pillars of salt. But if we do look back, we must also do so in the knowledge - which gives rise to profound uncertainties - that our physical alienation from India almost inevitably means that we will not be capable of reclaiming precisely the thing that was lost; that we will, in short, create fictions, not actual cities or villages, but invisible ones, imaginary homelands, Indias of the mind."

15. Tsiolkas, The Jesus man, 3527.

16. Tsiolkas, The Jesus man, 985.

17. Tsiolkas, The Jesus man, 3787.

18. See also Marilena Parlati, “Europe and its 'Ends'. Haunting (by) the Past in Christos Tsiolkas' Dead Europe", The Journal of the European Association of Studies on Australia, vol. 2, n², 2011, p. 42-52. 19. Tsiolkas, Loaded, p. 149.

20. See also similar examples of sexual orientalism provided by Todd Shepard, Sex, France, and Arab Men, 1962-1979, Chicago, University of Chicago Press, 2017 (also in French: Todd Shepard, Mâle décolonisation. "L'homme arabe" et la France, de l'indépendance algérienne à la révolution iranienne, Paris, Payot, 2017).

21. Tsiolkas, The Jesus Man, 2949.

22. Tsiolkas, The Jesus Man, 3527.

23. Tsiolkas, The Jesus Man, 4363.

24. Fanon, Black Skins, White masks, p. 22: «Yes, the black man is supposed to be a good nigger; once this has been laid down, the rest follows of itself. To make him talk pidgin is to fasten him to the effigy of him, to snare him, to imprison him, the eternal victim of an essence, of an appearance for which he is not responsible. And naturally, just as a Jew who spends money without thinking about it is suspect, a black man who quotes Montesquieu had better be watched. Please understand me: watched in the sense that he is starting something. Certainly I do not contend that the black student is suspect to his fellows or to his teachers. But outside university circles there is an army of fools: What is important is not to educate them, but to teach the Negro not to be the slave of their archetypes."

25. Tsiolkas, Barracuda, p. 166.

26. Ibid., p. 218.

27. Ibid., p. 279.

28. Tsiolkas, Barracuda, p. 44.

29. Janine Hauthal, “Writing back or writing off ? Europe as 'tribe' and 'traumascape' in works by Caryl Phillips and Christos Tsiolkas", Journal of Postcolonial Writing, 2015, Vol. 51, No. 2, p. 208-219. Retrieved from http://dx.doi.org/10.1080/17449855.2015.1012816 Accessed 31 May 2017? Graham Huggan \& Ian Law, Racim Postcolonialism Europe, Liverpool, Liverpool University Press, 2009 , p. 1. 
30. McCann, Andrew, Jeff Sparrow and Christen Cornell, "The Spectres Haunting Dead Europe", Overland 181, summer 2005, p. 27.

31. See also Nikos Papastergiadis, "Wog Zombie: The De- and Re-Humanisation of Migrants, from Mad Dogs to Cyborgs", Cultural Studies Review, 2009, 15 (2), p. 147-178.

32. Johan Höglund and Tabish Khair, "Introduction", In Transnational and Postcolonial Vampires. Dark Blood, Johan Höglund, Tabish Khair (Eds), Basingstoke and New York, Palgrave Macmillan, 2013, p. 1-2.

33. On the reception of the novel and the anti-Semitic theme, see Eleni Pavlides, Un-Australian fictions: nation, multiculture(alism) and globalisation, 1988-2008, Newcastle upon Tyne, Cambridge Scholars Publishing, 2013, p. 117 sqq.

Graham Huggan, "Vampires, again”, Southerly, 66, n³, 2006, p. 192-204 (quoted by McCann, Christos Tsiolkas and the Fiction of Critique, p. 145).

34. Tsiolkas, Dead Europe, p. 260.

Catherine Padmore (p. 61) also suggested "Dead Europe presents a powerful image of how ideologies can move between people through physical contact. When Isaac's skin touches his boyfriend's swastika tattoo, a relic of a neo-Nazi past, Isaac fears: "The ink [is] on [his] skin too" (255). Colin's shameful history clings to him through the tattoo and becomes absorbed into Isaac when their skins touch. I suggest this ink does not remain contained within the narrative: some of the ink from Colin's tattoo is transmitted through Tsiolkas' pages to the reader (a form of textually transmitted disease), so that the stain of anti-Semitism is on our skin too. See Catherine Padmore, “'Blood and land and ghosts": Haunting Words in Christos Tsiolkas' Dead Europe.', Journal of the Association for the Study of Australian Literature, Special Issue 2007: Spectres, Screens, Shadows, Mirrors, 2007, p. 52-64.

35. Jacques Derrida, The Work of Mourning, Pascale-Anne Brault and Michael Naas (Eds.), Chicago and London, University of Chicago Press, 2001, p. 41-42. Also cited in Padmore, "'Blood and land and ghosts", p. 61-62.

36. See Esther Benbassa, Jean-Christophe Attias (Eds.), La haine de soi. Difficiles identités, Bruxelles, Éditions Complexe, 2000 (on the genealogy of the concept of "Jewish self-hatred" coined in the 1930s by Theodor Lessing to the exploration of multifaceted self-loathing related to sex, sexual orientation, ethnicity and so on).

37. Iain Chambers, Migrancy, Culture, Identity, London and New York, Routeldge, Taylor \& Francis e-Library, 2001 p. 6. See also Kristeva : «Étrangement, l'étranger nous habite : il est la face cachée de notre identité [...]. De le reconnaître en nous, nous nous épargnons de le détester en luimême. » http://www.kristeva.fr/reflexions-sur-l-etranger.html

38. See Tzvetan Todorov, Nous et les autres. La réflexion française sur la diversité humaine, éditions du Seuil, Paris, 1989: « «Personne n'est intrinsèquement autre, il ne l'est que parce qu'il n'est pas moi », p. 356.

39. About the origin of the term "post-migratory", see Elleke Boehmer, Colonial and Post-colonial literature. Migrant Metaphors, New York, Oxford University Press, 2005, p. 250.

40. Parlati, "Europe and its 'Ends', p. 49.

41. Graham Huggan, Australian literature. Postcolonialism, Racism, Transnationalism, Oxford New York, Oxford University Press, 2007, p. vii: "Perhaps, as Andrew McCann suggests, Dead Europe is ultimately neither European nor Australian; rather, it is a 'global novel' which demonstrates, plausibly if pathologically, the 'sprawling networks of exchange, violence and desire that have been moulding the modern world for at least the past two hundred years' (McCann 2005: 28). Needless to say, however, this global novel throws off sparks for contemporary Australia, alluding both to hostilities against (illegal) migrants in the Howard-Ruddock era and to the repeatedly frustrated search for a national identity that remains haunted by the past from which it wishes to free itself, forcing the nation's younger citizens back into reliving the nightmares of another, older world." 
See also Eleni Pavlides, Un-Australian Fictions: Nation, Multiculture(alism) and Globalisation, 1988-2008, Newcastle upon Tyne, Cambridge Scholars Publishing, 2013.

42. Hauthal, "Writing back or writing off ?", p. 216-217.

43. Sneja Gunew, Post-Multicultural Writers as Neo-cosmopolitan Mediators, London, New York, Anthem Press, 2017.

44. See Elien DECLERCQ, “Écriture migrante”, "littérature (im)migrante”, "migration literature" : réflexions sur un concept aux contours imprécis', Revue de littérature comparée, vol. 339, no. 3, 2011, p. 301-310.

On "post-migratory" literature, see Ahmed Gamal, "The global and the postcolonial in postmigratory literature", In Networking the Globe: New Technologies and the Postcolonial, Florian Stadtler, Ole Birk Laursen (Eds), Routeledge, 2016, p. 94-106.

Boehmer, Colonial and Post-colonial literature, p. 250-251.

45. See Mandy Treagus, "A queer kind of belonging: identity and nation in Christos Tsiolkas's Loaded", CRNLE Journal (Centre for Research in the New Literatures in English), Flinders University of South Australia, 2000, p. 219-227. Mandy Treagus, "Queering the Mainstream: The Slap and 'Middle' Australia", Journal of the Association for the Study of Australian Literature, vol. 12 (3), 2012, p. 1-9. Ben Authers, 'I'm Not Australian, I'm Not Greek, I'm Not Anything": Identity and the Multicultural Nation in Christos Tsiolkas's Loaded', Journal of the Association for the Study of Australian Literature, vol. 4, 2005, p. 133-145.

See also Chantal Zabus, The Future of Postcolonial Studies, New York and London, Routledge (Routledge Research in Postcolonial Literatures), 2015, p. 189.

46. David Halperin, Saint Foucault: Towards a Gay Hagiography, New York, Oxford University Press, 1995, p. 62.

47. Aristea Fotopoulou, "Intersectionality Queer Studies and Hybridity: Methodological Frameworks for Social Research", Journal of International Women's Studies, 13 (2), 2012, p. 19-32. 48. See Sophie Coavoux, «Greek Diaspora and Hybrid Identities: Transnational and Transgender Perspectives in Two novels: Loaded, by Christos Tsiolkas (Australia) and Middlesex, by Jeffrey Eugenides (USA)», Transtext(e)s Transcultures, 7|2012. Retrieved from http:// transtexts.revues.org/451

49. Tsiolkas, Loaded, p. 114-115.

50. Tsiolkas, Barracuda, p. 508.

51. Tsiolkas, Loaded, p. 62.

\section{ABSTRACTS}

Through the prism of the complex entanglements of the migration and disease themes, the whole work of Christos Tsiolkas provides a wide range of disorders that affect the minds and the bodies of his "translated" subjects. His controversial representations of hyphenated subjects provide a critique of identities and identity politics through his interpretation of unhealthy imaginary of the migrant. In this way, Christos Tsiolkas goes beyond any binary approach based on a simplistic and superficial opposition between the "same" and the "other", categories which coincide with those of the "healthy" and the "unhealthy", and according to him, otherness does not exist per se, as an essence. Through the renewal of the cartography of otherness and by the way in which he subverts and relocates the unhealthy imaginary of his translated subjects, 
Christos Tsiolkas's writings can be considered to be an example of queer post-migratory literature.

\section{AUTHOR}

\section{SOPHIE COAVOUX}

Sophie Coavoux est Maître de conférences HDR de grec moderne à l'Université Jean Moulin (Lyon) et membre de l'IETT (Institut d'Études Transtextuelles et Transculturelles). Elle travaille essentiellement sur la littérature grecque moderne et sur le genre et a notamment publié Le développement de l'érotisme dans la poésie de Constantin Cavafy aux Presses Universitaires de la Méditerranée (2013) et Masculin / Féminin dans la langue, la littérature et l'art grecs modernes (dir.), Publication de l'IETT (2011).

Sophie Coavoux is Assistant Professor in Modern Greek Studies at the Jean Moulin University (Lyon), and a member of the IETT (Institute for Transtextual and Transcultural Studies). Her work mainly focuses on Modern Greek literature and gender and among her major publications are Le développement de l'érotisme dans la poésie de Constantin Cavafy (Presses Universitaires de la Méditerranée, 2013) and Masculin / Féminin dans la langue, la littérature et l'art grecs modernes (Ed.), publication de l'IETT (2011). 